\title{
BODY MASS INDEX AND ANXIETY IN POSTPARTUM PERIOD
}

\author{
Sari Narulita', Mella Yuria², Isti Istianah ${ }^{3}$ \\ 1Nursing Study Program, Binawan University, Jakarta-Indonesia. Email : sari@binawan.ac.id \\ 2Midwifery Study Program, Binawan University, Jakarta-Indonesia. Email : mella@binawan.ac.id \\ ${ }^{3}$ Faculty of Public Health, Indonesia University, Jakarta-Indonesia. Email : Isti@binawan.ac.id
}

\begin{abstract}
Background: The period of pregnancy and postpartum is the period when hormonal imbalance and adjustment become a mother (social factor) that makes a woman transition both physically and psychologically. Physically, the phases of pregnancy and postpartum greatly contribute to the increasing rate of obesity in women.

Purpose: This study aims to analyze the relationship between body mass index and postpartum women's anxiety level in Sukabumi City in 2014.

Methods: This research type is survey research using Cross Sectional method. The target population of the study was women who underwent labor in Sukabumi city of West Java with a sample of 97 people using random sampling technique.

Results: From the analysis of the relationship between body mass index and postpartum anxiety level there was a significant relationship. From the results of analysis of body mass index relationship with mild anxiety level and moderate-severe anxiety there is no significant relationship.

Discussion: The need to provide counseling about preparing before pregnancy or before birth in women. So that women are ready physically and mentally in pregnancy and labor so that it can reduce the number of anxiety disorders in postpartum women.
\end{abstract}

\section{Keywords: Body Mass Index, Anxiety, Postpartum Period}

\section{INTRODUCTION}

The period of pregnancy and postpartum is a period in which hormone imbalance and adjustment become a mother (social factors) that make women experience a transition both physically and psychologically (Vittayanont, Liabsuetrakul, \& Pitanupong, 2006; Maulana, 2009). Physically, the pregnancy and postpartum phases greatly contribute to increasing obesity rates in women (Gunderson, 2009; Keller, Records, Ainsworth, Permana, \& Coonrod, 2008). This increase occurs because of the increased supply of food consumed, increased fetal weight, increased blood supply to the fetus, increased fluid volume, accumulation of fat, and enlargement of organs. The standard body mass index according to the World Health Organization (WHO) for Asian populations is $<18.5$ for underweight, 18.5 to $<23$ for normal, 23 to $<25$ for overweight and $>25$ for obesity (Choi, Park, \& Shin, 2011). The Institute of Medicine (IOM) United States issued recommendations for weight gain during pregnancy. For a normal body mass index (BMI) then weight gain It is recommended that $11-16 \mathrm{~kg}$ during pregnancy, overweight $7-11 \mathrm{~kg}, 5-9 \mathrm{~kg}$ obesity, while for women with IMT underweight, you should increase $13-18 \mathrm{~kg}$ during pregnancy (Skouteris, McCabe, Milgrom, Kent, Bruce, Mihalopoulos \& Gale, 2012; O'Dwyer \& Turner, 2012; Maturi, Afshary, \& Abedi, 2011).The Measurements commonly used to measure body weight are the Body Mass Index (BMI)body mass index is calculated from the weight (kg) divided with height squared (meters) (Garner, Feeny, Thompson, Bernier, McFarland, Huguet, \& Blanchard, 2012). Obesity has a negative effect on physical and mental health. Some studies have shown a correlation between body mass index and anxiety level. women are twice as noisy 0 experience anxiety disorders compared to men (Claesson, Josefsson, \& Sydsjö, 2010; Onyango, \& Mott, 2011). In 2010 the prevalence of women with body mass index overweight and obesity in Indonesia was $21.7 \%$, while the prevalence in West Java was $22.8 \%$. And the prevalence of overweight and obesity for women in West Java it is $29.7 \%$ (Ministry of 


\section{BODY MASS INDEX AND ANXIETY IN POSTPARTUM PERIOD}

Health of the Republic of Indonesia, 2013). Based on data from the Sukabumi Health Agency, the number of babies born was 7,270 in 2011. From these data, the number of mothers giving birth was quite high in the city. Sukabumi, and increasing the risk of obesity in women (West Java Provincial Health Agencies, 2011). Based on the above review, women who are obese especially postpartum women allow higher anxiety disorders compared to women with a normal body mass index. Therefore researchers feel the need to further explore and analyze the relationship of body mass index with the anxiety level of postpartum women in Sukabumi.

\section{RESEARCH METHODS}

type of research is survey research and Cross Sectional. The target population of the study were women who underwent labor in Sukabumi City, West Java, with 100 samples using random sampling techniques. This study aimed to analyze the relationship of body mass index with anxiety levels of postpartum women in Sukabumi City in 2013.

\section{RESEARCH RESULTS}

Table 1. Characteristics of Body Mass Index and Levels of Anxiety N=100

\begin{tabular}{lccc}
\hline Characteristics & Frequency & $(\mathbf{n})$ & Percentage (\%) \\
\hline Index of Body Mass & & \\
Normal & 37 & 37.0 \\
Overweight & 24 & 24.0 \\
Obesity & 39 & 39.0 \\
Levels of Anxiety & & \\
without anxiety & 32 & 32.0 \\
mild anxiety & 50 & 50.0 \\
Moderate anxiety & 18 & 18.0 \\
\hline
\end{tabular}

The women in labor as 100 samples, a total of $37.0 \%$ had a normal body mass index, and to index overweight and obesity body mass as much as $63 \%$. Whereas when viewed from the level of anxiety, as many as $68 \%$ experienced postpartum anxiety disorders. While those who did not experience postpartum anxiety disorders were only $32 \%$.

Table 2. Relationship Between Body Mass Index and Anxiety N=100

\begin{tabular}{llccc}
\hline Variable & \multicolumn{2}{c}{ without anxiety } & \multicolumn{2}{c}{ Anxiety } \\
\hline BMI & $\mathbf{n}$ & $\%$ & $\mathbf{n}$ & $\%$ \\
Normal & 5 & 13.5 & 32 & 86.5 \\
Overweight & 12 & 50.0 & 12 & 50.0 \\
Obesity & 15 & 38.5 & 24 & 61.5 \\
\hline
\end{tabular}

Sari Narulita' Nursing Study Program, Binawan University, Jakarta-Indonesia. Email : sari@binawan.ac.id Mella Yuria ${ }^{2}$ Midwifery Study Program, Binawan University, Jakarta-Indonesia. Email : mella@binawan.ac.id Isti lstianah ${ }^{3}$ Faculty of Public Health, Indonesia University, Jakarta-Indonesia. Email : Isti@binawan.ac.id 


\section{BODY MASS INDEX AND ANXIETY IN POSTPARTUM PERIOD}

\section{$X^{2}=p=0.00$}

It can be seen that women who undergo labor in the city of Sukabumi with normal body mass index are more likely to experience postpartum anxiety disorder which is $86.5 \%$. Whereas the overweight category has the same percentage of those who are not worried about $50 \%$ who experience anxiety. The obesity category, women who had given birth in Sukabumi City were more likely to experience postpartum anxiety with a percentage of $61.5 \%$. Which was statistically significantly different from $p=0.00$.

Table 3. Relationship Between Body Mass Index and Anxiety N=100

\begin{tabular}{lcccc}
\hline Variable & \multicolumn{3}{c}{ Mild Anxiety } & \multicolumn{3}{c}{ Moderate to Severe Anxiety } \\
\hline BMI & $\mathrm{n}$ & $\%$ & $\mathrm{n}$ & $\%$ \\
Normal & 22 & 68.8 & 10 & 31.2 \\
Overweight & 10 & 83.4 & 2 & 16.6 \\
Obesity & 18 & 75.0 & 6 & 25.0 \\
\hline
\end{tabular}

$X^{2}=p=0.61$

The mild anxiety with moderate anxiety to severe, the relationship between the Body Mass Index is that women who have a normal body mass index are more likely to experience mild anxiety, with a percentage of $68.8 \%$. The overweight category was also more likely to experience mild anxiety with a percentage of $83.4 \%$, while the obesity category was also more often experienced mild anxiety disorder with a percentage of $75 \%$. And it can be concluded that post partum women in Sukabumi City are more likely to experience mild anxiety than moderate to severe anxiety. Statistically not significant with $p=$ $0.61 p$ value $>0.05$, where there was no significant relationship between body index mass and the level of mild anxiety and moderate-severe anxiety in postpartum women in the city of Sukabumi, West Java.

\section{DISCUSSION}

The level of anxiety, $68 \%$ experienced postpartum anxiety disorder. While those who did not experience postpartum anxiety disorders were only $32 \%$. This shows that women who give birth tend to experience postpartum anxiety disorders. This is consistent with the theory which states that anxiety levels tend to be higher in postpartum women (Zender, \& Olshansky, 2009; Teixeira, Figueiredo, Conde, Pacheco, \& Costa, 2009; Edhborg, Nasreen, \& Kabir, 2011). Anxiety can be defined as a great concern about the baby's condition and sometimes there is a great feeling of guilt over a mistake made by Manikkam, \& Burns. (2012). Many negative things due to the persistence of anxiety disorders in postpartum women: less sensitive, less responsive and reduce competence in babysitting. Women who experience anxiety disorders during pregnancy and postpartum become more overprotective of their babies. In addition, children's psychology can also experience disorders due to postpartum anxiety (Edhborg, Nasreen, \& Kabir, 2011).

Body Mass Index with postpartum anxiety level in Sukabumi City in 2013, it can be concluded that the anxiety level in postpartum women with body mass index is $86.5 \%$ and the highest category for nondepression is overweight body mass index. And from the results of the analysis of the relationship between body mass index and postpartum anxiety level, there

Sari Narulita' Nursing Study Program, Binawan University, Jakarta-Indonesia. Email : sari@binawan.ac.id Mella Yuria ${ }^{2}$ Midwifery Study Program, Binawan University, Jakarta-Indonesia. Email : mella@binawan.ac.id Isti Istianah ${ }^{3}$ Faculty of Public Health, Indonesia University, Jakarta-Indonesia. Email : Isti@binawan.ac.id 


\section{BODY MASS INDEX AND ANXIETY IN POSTPARTUM PERIOD}

was a significant relationship with $p$ value $0.00(p=$ $<0.05$ ).

The results of this analysis indicate that between body mass index has a significant relationship with postpartum anxiety level. The results of this study are in line with several previous studies, that body mass index in postpartum women has a significant relationship with increased postpartum female anxiety disorders (Zender, \& Olshansky, 2009; Teixeira, Figueiredo, Conde, Pacheco, \& Costa, 2009; Edhborg, Nasreen, \& Kabir, 2011). The body mass index increases the prevalence of anxiety disorders by $25 \%$ and the higher the level of a person's body mass index, the level of anxiety will increase (McElroy, Allison, \& Bray, 2006; Barden, Conley, \& Young, 2015).

And when viewed from the relationship of the Body Mass Index with the level of mild anxiety and moderate to severe anxiety, postpartum women who experience mild anxiety disorders tend to be experienced by women who have an index overweight body mass with a percentage of $83.4 \%$. And moderate-severe anxiety levels tend to be experienced by women who have a normal body mass index. And it can be concluded that post partum women in Sukabumi city are more likely to experience mild anxiety compared to moderate anxiety. Statistically the relationship between body mass index with mild anxiety and moderate-severe anxiety was not significant with a $p$ value of 0.61 ( $p$ $\Rightarrow$ 0.05). The obese and overweight groups experience mild anxiety even though there is no statistical relationship. However, from a normal BMI there was an anxiety of $86.5 \%$, so also those who were overweight and obese also felt mild anxiety. Thus from these data, anxiety that is quite high is likely to affect milk production and affect the development of the baby. In accordance with what was revealed by Ystrom (2012) that anxiety disorders and ASI have reciprocal relationships. Anxiety has an impact on breast milk production, and giving / stopping breast milk will have an impact on postpartum anxiety. Even early dismissal in breastfeeding has a significant relationship to postpartum anxiety levels.

The results of this study has similar with previous studies which showed that body mass index in postpartum women did not become at the postpartum anxiety level (Claesson, Josefsson, \& Sydsjö, 2010). The relationship between obesity and mental disorders (anxiety, depression, and stress) is very complex (Barden, Conley, \& Young, 2015). The body mass index is not the only postpartum anxiety factor. In addition to body mass index, hormone levels after childbirth also contribute to increased anxiety in postpartum women. Other factors that influence anxiety levels are the sex of the baby, level of income, infant weight, social support (Onyango, \& Mott, 2011; Teixeira, Figueiredo, Conde, Pacheco, \& Costa, 2009; Maturi, Afshary , \& Abedi, 2011; Whisman, Davila, \& Goodman, 2011).

\section{CONCLUSION}

The analysis of the relationship between body mass index and postpartum anxiety level there is a significant relationship. From the results of the analysis of the relationship between body mass index and the level of mild anxiety and moderate-to-severe anxiety there was no significant relationship.

\section{SUGGESTIONS}

The need to provide counseling about preparations before pregnancy or before birth in women. So that women are prepared physically and mentally during pregnancy and childbirth so that they can reduce the number of anxiety disorders in postpartum women in Indonesia, especially in Sukabumi City, West Java.

\section{REFERENCES}

Anniverno, R., Bramante, A., Mencacci, C., \& Durbano, F. (2013). Anxiety disorders in pregnancy and the postpartum period. In New insights into anxiety disorders. IntechOpen.

Barden, S., Conley, A., \& Young, M. (2015). Integrating health and wellness in mental health counseling: Clinical, educational, and policy implications. Journal of mental health counseling, 37(2), 152-163.

Choi, S. K., Park, I. Y., \& Shin, J. C. (2011). The effects of pre-pregnancy body mass index and gestational weight gain on perinatal outcomes in Korean women:

Sari Narulita' Nursing Study Program, Binawan University, Jakarta-Indonesia. Email : sari@binawan.ac.id Mella Yuria ${ }^{2}$ Midwifery Study Program, Binawan University, Jakarta-Indonesia. Email : mella@binawan.ac.id Isti lstianah ${ }^{3}$ Faculty of Public Health, Indonesia University, Jakarta-Indonesia. Email : Isti@binawan.ac.id 


\section{BODY MASS INDEX AND ANXIETY IN POSTPARTUM PERIOD}

a retrospective cohort study. Reproductive Biology and Endocrinology, 9(1), 6.

Claesson, M., Josefsson, A., \& Sydsjö, G. (2010). Prevalence of anxiety and depressive symptoms among obese pregnant and postpartum women: an intervention study. BMC public health, 10(1), 766.

Dinas Kesehatan Provinsi Jawa Barat. (2011). www.diskes.jabarprov.go.id.

Edhborg, M., Nasreen, H. E., \& Kabir, Z. N. (2011). Impact of postpartum depressive and anxiety symptoms on mothers' emotional tie to their infants 23 months postpartum: a population-based study from rural Bangladesh. Archives of women's mental health, 14(4), 307.

Garner, R. E., Feeny, D. H., Thompson, A., Bernier, J., McFarland, B. H., Huguet, N., ... \& Blanchard, C. (2012). Bodyweight, gender, and quality of life: a population-based longitudinal study. Quality of Life Research, 21(5), 813-825.

Gunderson, E. P. (2009). Childbearing and obesity in women: weight before, during, and after pregnancy. Obstetrics and Gynecology Clinics, 36(2), 317-332.

Keller, C., Records, K., Ainsworth, B., Permana, P., \& Coonrod, D. V. (2008). Interventions for weight management in postpartum women. Journal of Obstetric, Gynecologic \& Neonatal Nursing, 37(1), 7179.

Kementrian Kesehatan Republik Indonesia. (2013). Riset kesehatan dasar 2013. Jakarta: Badan Penelitian dan Pengembangan Kesehatan RI.

Manikkam, L., \& Burns, J. K. (2012). Antenatal depression and its risk factors: an urban prevalence study in KwaZulu-Natal. South African Medical Journal, 102(12), 940-944.

Maturi, M. S., Afshary, P., \& Abedi, P. (2011). Effect of physical activity intervention based on a pedometer on physical activity level and anthropometric measures after childbirth: a randomized controlled trial. BMC pregnancy and childbirth, 11(1), 103.
Maulana, M. (2009). Tanya Jawab Lengkap Dan Praktis Seputar Reproduksi, Kehamilan, dan Merawat Anak Secara Medis dan Psikologis. Yogyakarta: Tunas Publising, 194.

O'Dwyer, V., \& Turner, M. (2012). Caesarean Section and Maternal Obesity. In Salim, R.(ed.). Cesarean Delivery. InTech.

Onyango, M. A., \& Mott, S. (2011). The nexus between bridewealth, family curse, and spontaneous abortion among southern Sudanese women. Journal of Nursing Scholarship, 43(4), 376-384.

Skouteris, H., McCabe, M., Milgrom, J., Kent, B., Bruce, L. J., Mihalopoulos, C. \& Gale, J. (2012). Protocol for a randomized controlled trial of a specialized health coaching intervention to prevent excessive gestational weight gain and postpartum weight retention in women: the HIPP study. BMC Public Health, 12(1), 78.

Teixeira, C., Figueiredo, B., Conde, A., Pacheco, A., \& Costa, R. (2009). Anxiety and depression during pregnancy in women and men. Journal of affective disorders, 119(1-3), 142-148.

Vittayanont, A., Liabsuetrakul, T., \& Pitanupong, J. (2006). Development of Postpartum Depression Screening Scale (PDSS): a Thai version for screening postpartum depression. Journal-Medical Association of Thailand, 89(1), 1.

Whisman, M. A., Davila, J., \& Goodman, S. H. (2011). Relationship adjustment, depression, and anxiety during pregnancy and the postpartum period.c Journal of Family Psychology, 25(3), 375

Ystrom, E. (2012). Breastfeeding cessation and symptoms of anxiety and depression: a longitudinal cohort study. BMC pregnancy and childbirth, 12(1), 36

Zender, R., \& Olshansky, E. (2009). Women's mental health: depression and anxiety. Nursing Clinics, 44(3), 355-364.

Sari Narulita' Nursing Study Program, Binawan University, Jakarta-Indonesia. Email : sari@binawan.ac.id Mella Yuria ${ }^{2}$ Midwifery Study Program, Binawan University, Jakarta-Indonesia. Email : mella@binawan.ac.id Isti Istianah ${ }^{3}$ Faculty of Public Health, Indonesia University, Jakarta-Indonesia. Email : Isti@binawan.ac.id 